\title{
SOME ANALYSES IN THE PSYCHOPATHOLOGY OF EVERYDAY LIFE
}

\author{
BY H. W. FRINK, M. D.
}

Instructor in Neurology and Chief of the Neurological Clinic Cornell Medical College, New York.

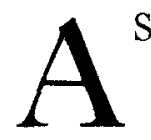

$\mathrm{S}$ Freud has shown in his Psychopathologie des Alltagslebens, those small disturbances of mental functioning such as slips of speech, mistakes in writing, the occasional forgetting of familiar names, etc., are not mere chance happenings but have their definite determinants. In almost every instance it can be demonstrated by careful investigation that the disturbance was brought about by the influence of some stream of thought or group of ideas which for the time being lay outside the field of the individual's consciousness. These side streams are not very far removed from consciousness, in perhaps the majority of instances. They belong rather to the foreconscious than to the unconscious proper, and thus are usually quite accessible to conscious introspection.

The disturbances of functioning produced by these foreconscious or unconscious trends are brought about in different ways. Sometimes the malfunctioning expresses the fulfillment of a pleasure-striving; at others it represents a defense against a painful trend or idea, etc. In any case the disturbance is one which, upon analysis, may be expressed in terms of motive and, in miniature, is identical in psychological structure with those greater disturbances which we know as psychoneurotic and psychotic symptoms. The difference between the "psychopathology of everyday life" and actual psychopathology or psychic illness is, in essence, merely a quantitative one.

Perhaps the most common example of these minor disturbances is that of temporary inability to recall some perfectly familiar word or name. Lapses of memory of 


\section{Some Analyses in the Psychopathology of Evervday Life}

this variety are usually found upon analysis to be phenomena of defense. The name or word is one which was included in or closely associated with a group of ideas painful to the conscious personality of the individual and which in consequence had been included within the protective resistances tending to oppose the entrance of these painful ideas into consciousness. The examples which follow are sufficiently understandable without further introduction.

I. A friend once asked me if I knew of a firm which could supply a certain commodity he desired, but upon replying that I did, I found myself unable to remember the name of the firm, although I did remember the location of their place of business-a large downtown office building.

A few days later, as I happened to be passing this building, I stepped in, and upon consulting the directory of its tenants found that the name I had been unable to recall was Pond. I attempted afterward to analyze my forgetting with the results that are here recorded.

My first association with the word Pond was that a certain Dr. Pond had been a pitcher on the old Baltimore baseball team., Next I thought of Indian Pond, where I used to go fishing as a small boy, and I had a memory picture of myself throwing into the water the large stone used as an anchor for the boat. Then I thought of a man named Fischer who is at present a pitcher for the New York Americans.

Continuing, I thought of Pond's Extract and of the fact that it contains witch hazel. This reminded me that I used witch hazel to rub my arm when in my school days I was pitcher on a baseball team. I also thought of a certain fat boy who was a member of the same team and recalled with amusement that in sliding to a base this boy once went head first into a mud puddle, so that as he lifted his face plastered with dirt this, combined with his marked rotundity, had given him an extremely laughable and pig-like appearance. I further recalled that at that time I knew a boy nicknamed "Piggy" and that at a later time I had been nicknamed "Pig." 
At this point I was interrupted for a few moments, and when I returned to the analysis the word Pond brought the associations: Ponder-think-"sicklied o'er with the pale cast of thought"-Hamlet - the memory of my having referred to a certain village as a hamlet - the recollection that a farmer in this village once told me that a spiteful neighbor killed two pigs and threw them into his (the farmer's) well.

Then there suddenly occurred to me the following incident from my seventh year, which appears to have been the cause of my forgetting the word Pond.

At the time I refer to I had a dog to which I was greatly attached. My brother and I were playing one day on the edge of a small pond near our house, and this dog was in the water swimming. We began to throw small stones into the water in front of the dog, and as each stone struck the surface he would jump for the splash, try to bite it, and bark in joyous excitement. Finally, I was seized with the malicious desire to scare the dog and, picking up a stone weighing three or four pounds, I threw it, intending it to strike just in front of him and frighten him by its enormous splash. Lnfortunately, my aim was bad. The big stone struck the dog squarely upon the nose and stunned him, so that he sank beneath the surface and was drowned.

My grief over this incident was without question the greatest that I experienced in my childhood. For days I was utterly inconsolable, and for a long time there were occasions when I would be so overcome with sorrow and remorse as to cry myself to sleep at night. I suppose, however, that mygrief seemed greater than it actually was. That is to say, it was exaggerated to serve as a compensation and penance for the painful perception that a cruel impulse on my part was responsible for the dog's untimely end.

At any rate, as is plain, the memory of the incident was a very painful one, and, in consequence, I had good reason to wish to forget not only the incident itself but also any word (such as Pond) which might serve to bring it before my consciousness.

A matter that is not without interest in this analysis is the relevancy of my seemingly irrelevant associations. For instance, my first association-that of the pitcher, Dr. 


\section{Some Analyses in the Psychopathology of Everyday Life}

Pond-contains three ideas connected with the repressed memory; viz., Doctor (myself), Pond (the place of the incident), and pitcher (one who throws). My second association - concerning Indian Pond and my throwing into the water the big stone used as anchor-is equally relevant. Indian Pond is in the same town as the other pond in which the dog was drowned; my memory of throwing overboard the anchor is connected with the memory of throwing into the water the other big stone which caused the dog's death, etc.

The association pig which came up several times in the latter part of the analysis seems at first glance to have no connection with the concealed memory. A connection does exist, however. The letters P-I-G reversed are G-I-P, which spells the name of the dog. Thus the association concerning the pig-like boy and the mud puddle-which contains the elements $P-I-G$, baseball (i.e., throwing), and water-or that of the farmer and the pigs- $P-I-G$, death, throwing, and water-is seen to be perfectly relevant. Hamlet and the quotation from it gain a mediate relevancy through the drowning of Ophelia.

II. A friend of mine who lives in a suburb of New York once telephoned me to go to dinner and the theater with him. I met him as he suggested and during the conversation at dinner he said in commenting on an occurrence that had greatly surprised him, "I could not believe the information of my own senses." "No, that isn't right;" he went on, interrupting himself, "we don't speak of doubting the information of our senses-some other word is used. What is it? The reality of our senses?"

I replied that what he had meant to say was that he could not believe the evidence of his senses, and asked, laughing, "Why do you want to forget about evidence? You haven't committed a crime, have you?"

"No," he replied, apparently somewhat startled, "I haven't committed any crime, but I'm afraid I'm about as badly off as if I had done so. It's quite astonishing how near you came to the truth."

He then went on to explain that a woman with whom he had had business relations over quite a long period had 
become incensed over some trifle and made certain unjust and untrue accusations against him, which she threatened to make public in the form of a suit. $\mathrm{He}$ had felt little concern over the matter until there suddenly came upon him the realization that if she did carry out her threat-a thing he felt she was quite capable of doing-his situation would be an extremely unpleasant one, for not only had he no way of positively disproving her allegations, but there were certain pieces of circumstantial evidence which she could bring forward and which, in spite of his actual innocence, would readily create against him a strong presumption of guilt. Thus the situation might well be a serious one for him. Naturally, he was greatly disturbed, and he had been worrying about evidence and proof almost to the point of distraction. At last he angrily told himself that there was nothing to be gained by worry and that the best thing would be to put the matter out of mind until the woman saw fit to make some definite move. With this end in view he jumped on a train and came to New York, hoping to find something to divert his thoughts to more pleasant themes.

His failure to remember the word evidence as a part of the familiar phrase he wished to use was, as may now be seen, a part of the more or less automatic defense designed to protect against reproduction in his consciousness of the disagreeable theme in which the question of evidence formed such a conspicuous part.

III. One of my patients, while discussing baseball with a friend, wished to mention a famous Chicago outfielder who has now passed into obscurity. But, though this player's name has for years been thoroughly familiar to him, he was surprised to find that at the time he was utterly unable to recall it. He could remember very clearly the man's appearance and history, and he also recalled that his name used to head the Chicago batting order, followed by that of Schulte, which he knew it resembled to the extent of beginning with an sh sound. His friend, who is not a close follower of the game, did not remember the player at all. 
When the patient reported the occurrence to me I was able to tell him that the name in question was Sheckard. Hardly had I pronounced this name when there came unbidden to the patient's mind the word checkered and the phrase a checkered career. This phrase, which, as then appeared, had in his mind a somewhat sinister connotation. implying unsavory adventure, dissoluteness, and ultimate disaster, accurately summed up a theme which at the time was most disturbing to the patient. Not only had his past contained a considerable number of somewhat discreditable adventures, but at the time he seemed unable to resist certain temptations which bid fair to produce a repetition of the past, and also to involve him in new difficulties which might easily end in the wrecking of his future. In short, he had reason to feel that his career, instead of being one of which he could be proud, might become one of the checkered variety, according to the most sinister acceptation of the term.

Instead, however, of facing these problems and working out a solution, he had chosen to put them out of mind and, as far as possible, ignore their existence. His inability to recall the name Sheckard was a by-product of this effort. The similarity in sound between Sheckard and checkered was so close that for him to be conscious of the former might also involve his being conscious of the latter, and thus bring before his mind the phrase a checkered career and all that, in his life, it comprehended.

It may be added that the likelihood of this theme being brought to his mind by the conversation with his friend was particularly great, because he had recently heard that a certain great ball player had been forced to retire from the game by the effects of venereal disease. With this player he could identify himself, both because he too had once possessed considerable prominence in baseball and also because he had suffered a venereal infection, which at the time was giving him some anxiety. This player had once been a member of the Chicago team, and for that reason the mention of Sheckard might easily have served to recall him, and, by means of the existing identification, to bring into consciousness the theme of "a checkered career" and its 
possible disastrous ending. On account of this there was required a defensive forgetting that under other circumstances might not have been necessary.

There follow two cases of omission in writing. The second differs from the foregoing examples in that it expresses a positive wish-fulfillment rather than a defense against something painful.

IV. A stenographer, after transcribing from his notes a long letter that had been dictated to him, discovered that he had omitted from the transcript the following sentence which was contained in his notes: "Divorce is out of the question, for the man is a Roman Catholic." There were no other omissions or mistakes.

The reason for this mistake was that the man, who was very unhappy in his married life, was secretly pondering the question of divorce, realizing at the same time that it would be by no means easy for him to secure one. His omission or forgetting of the sentence quoted is readily explained by the fact that the idea that "divorce is out of the question" was to him a painful one.

V. While serving as secretary of a certain society I found, when called upon to read the minutes of the previous meeting, that in writing them up I had entirely omitted the usual formula "The President, Dr. Blank, in the chair."

The meeting at which I discovered this mistake was the one at which officers were nominated for the ensuing year. I had privately entertained hopes that at this meeting I might be nominated for the office of president. The minutes of the previous meeting I had written up from notes just before I left the house to attend this one. My mistake was an unconscious wish-fulfillment, which deposed the occupant of the presidential chair in order that I might have his place.

The following example of a mistake in speaking is that of a disturbance produced by the unwished-for intrusion of a disagreeable theme. It does not correspond to a wish- 
fulfillment but may be best classified as an example of partial failure of defense.

VI. At one time I had a female patient who possessed a very exaggerated reluctance to admitting that she was wrong in anything no matter how trivial the matter might be. If any one called her attention to a mistake, however small, she would either deny most vigorously that she had made it, or, if this was entirely out of the question, she would seek in every way to excuse herself for it.

This peculiarity of hers was a topic of conversation during one of her visits to me, and I had asked, "Have you no idea of the reason for your so great unwillingness ever to admit yourself in the wrong?"

"No, I haven't," she replied, pretending to think hard, "Is it self-ab-self-effacement?"

As is fairly evident, the word she had started to use was self-abasement, and this she acknowledged when I called her attention to the matter. Her substitution for it of the word self-effacement, one would suppose, must have been a defense of some sort; that is, the word self-abasement must have bordered on or been contained in some group of ideas painful to her.

This I explained to her, and she replied, "Oh, I didn't know that you expected me to tell you all about things that are past-I stopped it two years ago."

Thus it is to be seen that the idea against which her substitution defended was that of "self-abuse."

And so in a way she had answered the question I asked her. Her guilt complex about masturbation was one of the causes of her reluctance to admitting that she was ever wrong. It was as if as a defense against admitting herself guilty in that regard (and in one or two other particular things) she had resolved never to admit herself wrong in anything, very much as, in warfare, the first line of defense is set up far in advance of the real point of objective of the attacking enemy.

Incidentally, it may be pointed out that the patient's question, "Is it self-effacement (or abasement)?"-an obviously absurd response to my question-is a good index 
of her resistances. It is not difficult to see that her conscious thought was that the probable reason for her unwillingness to admit mistakes was not self-abasement, but, on the contrary, pride. But in her mood of resistance and antagonism she gave the answer that to her seemed just the opposite of the one expected.

An example of involuntary self-revelation somewhat similar to this one is that of a patient who said "sins of emission" when he had meant to say "sins of omission." 